\title{
Carcinoma of the Eyelid Pathologic Distant Metastasis TNM Finding v7
}

National Cancer Institute

\section{Source}

National Cancer Institute. Carcinoma of the Eyelid Pathologic Distant Metastasis TNM

Finding v7. NCI Thesaurus. Code C88573.

A pathologic finding about one or more characteristics of carcinoma of the eyelid,

following the rules of the TNM AJCC V7 classification system as they pertain to distant

metastases. There is no pathologic M0 for carcinoma of the eyelid. (from AJCC 7th Ed.) 